June 1992

\title{
Psychoanalytic Approach to Child Development
}

Jeanette M.S. Zaimes, M.D.

Thomas Jefferson University Hospital

Follow this and additional works at: https://jdc.jefferson.edu/jeffjpsychiatry

Part of the Psychiatry Commons

Let us know how access to this document benefits you

\section{Recommended Citation}

Zaimes, M.D., Jeanette M.S. (1992) "Psychoanalytic Approach to Child Development," Jefferson Journal of Psychiatry. Vol. 10 : Iss. 2 , Article 14.

DOI: https://doi.org/10.29046/JJP.010.2.011

Available at: https://jdc.jefferson.edu/jeffjpsychiatry/vol10/iss2/14

This Article is brought to you for free and open access by the Jefferson Digital Commons. The Jefferson Digital Commons is a service of Thomas Jefferson University's Center for Teaching and Learning (CTL). The Commons is a showcase for Jefferson books and journals, peer-reviewed scholarly publications, unique historical collections from the University archives, and teaching tools. The Jefferson Digital Commons allows researchers and interested readers anywhere in the world to learn about and keep up to date with Jefferson scholarship. This article has been accepted for inclusion in Jefferson Journal of Psychiatry by an authorized administrator of the Jefferson Digital Commons. For more information, please contact: JeffersonDigitalCommons@jefferson.edu. 


\title{
Psychoanalytic Approach to Child Development
}

\author{
THE COURSE OF LIFE \\ VOL III \\ MIDDLE AND LATE CHILDHOOD \\ Stanley I. Greenspan, M.D. and George H. Pollock, M.D., Ph.D., Editors \\ International Universities Press, Inc. \\ 1991, revised edition \\ 562 pages $\$ 65.00$
}

\section{by Jeanette M.S. Zaimes, M.D.}

One of the most common critisms of analytic theory by students, residents and mental health professionals is that changing views of the roles of men and women in today's society are seldom addressed by analysts in their writings on child development. The Course of Life, vol. III is therefore a must-read for students and residents as well as others in the field. It is one in a series of texts on the psychoanalytic view of child development, which was first published in 1980 and has been recently revised and updated. This volume covers childhood from 4 years old through 10 years old. Each chapter is written by a different author so the book represents a series of essays on the oedipal and latency periods of childhood. As such, the style of writing and perspective of the author vary widely; yet as a text it is extremely readable and presents a coherent and stepwise description of this period of development.

There are a total of 22 chapters. Roughly, the first half of the text discusses theory of normal development and the second half discusses psychopathology of the oedipal and school-aged child. In the first chapter, Nagera presents an excellent discussion of the controversy around female psychology and the resolution of the oedipal stage. In chapter two, Lampl-de Groot discusses the influence of early development on the oedipal constellation. This was the only chapter that I did not enjoy reading. It was an harangue on child care outside the home specifically, and on the ills of the world in general. It would be better left to an editorial than as a chapter in a comprehensive text. Chapter three by Kestenberg is a mixture of complex research in which I found the explanations of the methodology hard to follow. However, there were some absolutely delightful examples illustrated with children's fantasies that were a pleasure to read.

Chapter five by Pruett discussed the findings of studies of fathers as primary care providers of babies and during the first six years of development. This is a much needed and appreciated effort. Pruett looked at a number of studies that investigated the effects of men as primary caregivers, including both changes observed in this 
population and discussion on aspects that were observed not to change. Pruett also includes his view of much needed research in the future. Many women physicians have found creative alternatives for the care of their children and may find this chapter of particular interest. His conclusions are very reassuring to those families that are reliant on fathers to provide the bulk of the care for small children.

In chapter six Stoller provides a comparison of Freud's view of male supremacy to what we know now biologically, as well as an historical review of objections to Freud's point of view from other analysts. He goes on to suggest that there is a primary femaleness, both biological and psychological (at least psychological in children whose primary caretaker in the first 24 months is female). Stoller argues for an initial struggle in boys with separation-individuation to establish a masculine identity in the face of the mother-child symbiosis. If infants perceive themselves as one with mother, then boys must separate their sexual identity and guard against intimacy with women. Stoller argues that this would explain many of the cultural rituals, customs, neuroses and eroticisms designed to guard against intimacy with women. Stoller further argues that male transexualism represents a failure of this separation. This chapter is fascinating and a stimulating antedote to a previous era of male primacy psychology.

The chapters of this book concerned with child psychopathology are all excellent. They are filled with examples and case studies that make for easy reading and comprehension. Chapter 12: A Developmental Approach to Systematic Personality Assessment, takes the reader through a comprehensive work-up of a six-year-old boy which illustrates this chapter in a clear and readable manner.

It is fair to say that this book is recommended to all residents as a must-read, and to any mental health professionals beyond training level, as a timely update and stimulating and thought-provoking reading. It contributed richly to my education. 